\title{
Sürgünde Örgüt: Suriye İhvanı
}

\section{Bulut GÜRPINAR*}

\section{Özet}

İslam'ın doğuşundan itibaren, birçok İslam mezhebi, tarikatı, fraksiyonu ve örgütü ortaya çıkmıştır. Bu hareketler içerisinde önemli bir yere sahip olan İhvan (İhvan-ül Müslimin/ Müslüman Kardeşler), ilk olarak Mısır'da 1928 yılında İngiliz manda rejimine karşı kurulmuş, 1940'ların ortasında bu hareketten etkilenerek Suriye'de benzer bir örgüt oluşmuştur. Suriye İhvanı parlamentoda temsil edilmiş, bazı üyeleri Bakan olarak görev almış ancak Baas rejimi ile birlikte şiddet hareketleriyle anılarak yasaklanmıştır. Beşar Esad dönemi ve Arap isyanları ile birlikte yeniden gündeme gelen Suriye İhvanı, İslamcı örgütlenmeler arasında önemli bir role sahip olmasına, Suriye'de gelişimi ve siyasal etkinlikleri Türkiye'yi yakından ilgilendirmesine karşın Türkiye'de gereken akademik ilgiyi bulamamıştır. Bu eksiklikten yola çıkan çalışma, Suriye muhalefeti içerisinde hala etkin bir konumda olan Suriye İhvanı hakkında bilgi vermeyi amaçlamaktadır. Bunun için öncelikle İslamcı örgüt tanımının içeriği tartışılacak, ardından İslamcı örgütler içerisinde Suriye İhvanı'nın kuruluşu, amaçları, geçirdiği değişim, politik konumu ve örgüt stratejisi, son gelişmelerle birlikte muhalefet içerisindeki konumu sergilenmeye çalışılacaktır.

Anahtar Kelimeler: Suriye İhvanı, Suriye, İslamcılık, İslami hareket

\section{Syrian Ikhwan: An Organization in Exile}

\begin{abstract}
Since the beginning of Islam, a great number of Islamic sects, orders, fractions and organizations have emerged. A significant one among these movements, the Muslim Brotherhood (Al-Ikhwan AlMuslimun fi Suriya/ MB), was first established against the British mandate in Egypt in 1928, and it spread to Syria in the mid 1940s. The MB was represented in the Syrian parliament and even some members served as ministers. Yet, the MB was banned due to its act of violence after the 1963 coup

* Araş. Gör. Dr., Gebze Yüksek Teknoloji Enstitüsü, İşletme Fakültesi, Kocaeli. E-mail: bulutgurpinar@gmail.com. Çalışmadaki katkılarından dolayı Prof. Dr. Gencer Özcan’a teşekkür ederim.
\end{abstract}


that brought the Baath Party to power. Also with the impact of the Arab revolts The Syrian Muslim Brotherhood has currently regained its significance once again in the Bashar al-Assad era as one of the most important constituents of the oppositional Islamic movement. Moreover, the MB has begun to hold most meetings in Turkey after the Syrian War since its development and political activities in Syria have become a particular concern to Turkey. However, the issue can hardly find a place in the academic articles in Turkey. Having realized this lack of interest, this study aims to provide an overview of the Muslim Brotherhood of Syria. Therefore, the study will start with a discussion on the content of the "Islamic organization" definition. Then, the Syrian Muslim Brotherhood will be elaborated in terms of its establishment, objectives, change process, political position and organization strategy as well as its current position in the opposition together with recent developments in the Islamic world.

Keywords: Syrian Muslim Brotherhood, Syria, Islamism, The Islamic Movement

\section{Giriş}

İslamcılık, genellikle, gündelik hayattaki politik, ekonomik ve kültürel sorunlara karşı İslam temelli çözüm arayışlarını savunmaya dönük Müslüman sosyal hareketler ve tutumlar olarak tanımlanabilir (Martin ve Barzegar, 2010: 2). İslamcı hareketin kuruluşu, organizasyonu ve süreci, İslamın anlam, kimlik ve kolektif eylem konularında tartışmanın önemli bir unsurudur. İslamcı hareket, İslamın verdiği ilham ve ideolojik dünya görüşü ile diğer hareketlerden ayrılır (Wiktorowicz, 2004: 3). İslamcılık, Müslüman birikimin uzun süreli reddedilişine bir tepki olmanın yanı sıra (Calvert, 2008: 5), konjonktürel gelişmeler çerçevesinde sömürgeciliğe karşı gelişen Batı karşıtı bir akımdır. Şerif Mardin’in tarihsel gelişimi temel alan tanımına göre İslamcılık "İslam topluluklarında, önceleri belli belirsiz birtakım eğilim, özlem ve arayışlar olarak beliren sosyal kıpırdanmaların 19. yüzyılın sonuna doğru daha bilinçli bir akım olarak şekillenmesine verilen addır” (Mardin, 1992: 1936-1940). ${ }^{1}$ Müslümanlar; kendilerini Batı işgali ve Batılılaşmış kimlikten kurtarmak için "sahici” bir İslamcı yaşam tarzı arayışına yönelerek, küreselleşmesinin dayattığı çağdaş Batı modernliğine karşı eleştirel bir duruş içine girmişlerdir (Göle, 1991: 36). Batıya ve Batıcılığa karşı gösterilen reaksiyon, Müslüman ülkelerde İslamcı hareketlerin belirgin bir özelliği olarak ortaya çıkmıştır (Akdoğan, 1999: 3). Kemal Karpat’a (2001: 21) göre, İslamcı hareketler, İslam’ın temellerini aramaya dönüş fikriyle yerel ya da bölgesel başlamış ve giderek/ eş zamanlı olarak (Rusya, Hollanda, İngiltere, İtalya, Fransa’ya karşı Orta Asya, Kafkasya, Doğu Hindistan, Kuzey Afrika ve Mısır'da) askeri direniş hareketine dönüşmüştür. ${ }^{2}$ Diğer yandan

\footnotetext{
${ }^{1}$ Ayrıca postmodernist ve İslamcı söylem arasında benzerlikler ve farklılıklar için bkz. Gülenç, (2011: 121-136).

2 Türköne’ye (1994: 13-23) göre İslamcilık, Namık Kemal başta olmak üzere bir grup Osmanlı aydını tarafından modern dünyanın ve batıdaki seküler akımların meydan okumalarına karşı koyma endişeleriyle siyasi bir ideolojiye dönüştürülmüsștür. Osmanl'da İslamcılık'tan ilk söz eden isimlerden biri olan Yusuf Akçura, 1904'de yayımlanan Üç Tarz-ı Siyaset makalesinde imparatorluğun çözülmekten kurtarılması için Osmanlıcılık, İslamcılık ve Milliyetçilik görüşlerini karşılaştırmıştır. Modern devlet ideolojisi oluşturabilmek için 2. Abdülhamid, İslamcı dirilişin düşüncelerini ve temel yöntemlerini benimsemiş, yeniden biçimlendirmiş ve geliştirmiştir. Osmanlıc1lığın imparatorluğu bir arada tutmada başarısız olmasıyla Osmanlı devleti Fransız tipi homojen toplum yaratma amacıyla İslamcılığı benimsemiştir (Akçura, 2011).
} 
özellikle otoriteryen yönetimler altında, kitleler modernizasyon projesinin yarattığı olumsuz etkilerin azaltılmasina resmi kanallardan katılamayınca, politik hareketler sistem tarafindan çoğunlukla yasaklanınca, İslamcı hareket politik hoşnutsuzluğun doğal bir ifade aracı haline gelmiştir (Wiktorowicz, 2004: 8).

Roy’a (2005: 16) göre, İslamcllığın üç coğrafi ve kültürel kutbu vardır: Sünni Arap Ortadoğu, Sünni Hint alt-kıtası ve İran-Şii alanı; Arap dünyasından kopuk Türkiye. Ancak günümüz İslamcı düşüncesinin ve örgütlerinin temelinde Hasan El-Benna ${ }^{3}$ tarafından Mısırda kurulan İhvan ve Ebul Ala Mevdudi tarafından Hindistan'da kurulan Cemaat-i İslami Partisi görülebilir. El-Benna, 1928'de İhvan’ı "Kur’an bizim anayasamızdır" diyerek kurmuş (Dekmejian, 1995: 9), daha sonra Suriye İhvanı (S. İhvanı) oluşmuştur. İhvan hareketini diğer İslamcı örgütlenmelerden farklı ve önemli kılan, İslamcılar arasında ilk siyasal talepli örgütlenme olmasıdır (Tekin ve Akgün, 2011: 661). Bugün, İhvan, aynı ad ve hedefleri benimsemiş oluşumlarla altı kıtada 72 devlete yayılmış en önemli "İ̇lami muhalefet" gurubunu temsil etmektedir (Karaman, 2012). İhvan, günümüzde önemini artırarak, özellikle Arap isyanları ile birlikte kimi ülkelerde iktidara taşınır/yeniden devrilirken, Suriye bağlamında muhalefetin önde gelen unsuru olmuştur.

İslamcı örgütlenmeler arasında önemli bir role sahip olan İhvan hakkında Türkiyede yapılan çalışmaların sınırlı sayıda olması ilgi çekicidir. ${ }^{4}$ Bu çalışmaların da neredeyse tamamının, İhvan’nn Mısır'da ortaya çıkışı ve gelişimi ile ilgili olması ayrıca ilginçtir. Arap isyanları ve sonrasında Suriye'de patlak veren savaşta İstanbul'da ve Antalyảda muhaliflerin düzenlediği toplantılarda S. İhvanı öne çıkmıştır. ${ }^{5}$ İlerleyen günlerde birçok ülkeden çok sayıda Suriye rejim muhalifi Türkiyeye gelmiş ve dış basında İstanbul, bir anlamda muhalefetin merkezi olarak sunulmuştur (Chulov, 2011). Dış politikada, Türkiye ilk kez devlet-dışı muhalif bir aktörle bu kadar yoğun ve açık biçimde anılmaya başlamıştır. İhvan'dan Türkiye'ye dönük olumlu mesajların yanı sıra, ${ }^{6} \mathrm{~d}$ ış basında Türkiye için "Müslüman Kardeşler'le bağ kurmuş" ifadeleri yer almaya başlamış, ${ }^{7}$ Türkiye

${ }^{3}$ Hasan El-Benna, Arap dünyasında siyasal İslam kavramını ilk kez formülleştiren kişi olarak kapsayıcı ve eylemci bir İslam için çağrıda bulunmuş, takipçilerine beş hedef göstermiştir: 1- Ferdin tekamülü, fert bazında İslam’ın yaşanması, 2- Aile bazında İslam’ın hayata kazandırılması, 3- İslam’ın topluma kazandırılması, 4- Devlet bazında İslam’nn tekrar yaşanması, 5- İslam dünyasında tekrar bu ümmetin yeniden teșekkülü ve tekemmülü. (Canatan, 1995: 73.)

4 Türkiye’de İhvan’ı inceleyen çalışmalar için bkz. Bulut (1994: 306-321), Baban (2006); Çakmak (2007: 69-98) ve Çağlayan (2010).

5 Örneğin, 26.04.2011'de Mazlumder çatısında S. İhvanı Genel Sekreteri Muhammed Riyad Şakfa ve Siyasi Büro Şefi Muhammed Faruk Tayfur’un da katıldığı "Suriye için İstanbul Buluşması" düzenlenmiştir (Mazlumder, 2011). 1 Haziran 2011'de "Değişim İçin Suriye Konferansı" ismiyle Antalya'da yaklaşık 300 Suriye muhalifi bir otelde 4 günlük konferans düzenleyerek, birleşik bir hareket yaratmaya çalışmışlardır. (Sly, 2011) 23 Ağustos 2011'de İstanbul'da gerçekleșen geniş katılımlı toplantıda, Suriye Ulusal Konseyi kurulmuştur (Syrian National Council, 2011).

${ }^{6}$ S. İhvanı Siyasi Büro Şefi Faruk Tayfur, Suriye ve bütün Arap alemi için en uygun yönetim modelinin bugün Türkiye'de yürürlükte olan model olduğunu söylemiştir. Tayfur, Türkiye'nin başlatmış olduğu ilişkilerden dolayı işbirliğinin en üst seviyeye çıktığını belirtmiştir (Mehmet, 2011).

7 New York Times'da Şubat 2011'de yayımlanan analizde, “Erdoğan’n partisi zaten Müslüman Kardeşler'le bağ kurmuş durumda” ifadesi kullanılmıştır. Gazete, İsrail Başbakanı Benjamin Netanyahu’nun eski başdanışmanı ve Kudüs Halkla İlişkiler Merkezi’nde araştırmacı olan Dore Gold’un, "Müslüman Kardeşleri’nin üç üyesinin İsrail komandolarının baskınına uğrayan Mavi Marmara gemisinde bulunduğu" iddiasına yer verilmiş, Gold’un "AKP ile Müslüman Kardeşler arasında büyük bir ideolojik uyumluluk var” sözleri aktarılmıştır (Thomas Jr., 2011). 
gündeminde de Türkiye ile ilişkileri tartışılmaya başlanmıştır. ${ }^{8}$ S. İhvanı’nın gelişimi ve siyasal etkinlikleri Türkiyeyi yakından ilgilendirmesine karşın gereken akademik ilgiyi bulamamıştır. Bu eksiklikten yola çıkan çalışma, S. İhvanı’nın ortaya çıkışını, siyasal harekete dönüşmesini, Suriyede siyasal iktidarla çatışma ve uzlaşma süreçlerini, son gelişmeler bağlamında Suriye muhalefeti içerisinde oynadığı rolü tartışmayı amaçlamaktadır.

\section{Suriye İhvanı'nın Kuruluşu ve Özellikleri}

Hasan El-Benna Arap dünyasında ilk olarak yardım ve eğitim faaliyetleri biçiminde örgütlenerek kapsayıcı ve eylemci bir İslam için çağrıda bulunmuş, "Kư’an bizim anayasamızdır" diyerek 1928 yllında Mısır'da İhvan’ kurmuştur. İhvan hareketi, İslamcı örgütlerin tanımına da uyan biçimde, İngiliz kolonyalizmine karşı "mevki ve onur sahibi olmama duygularıyla baş etmek üzere” (Lia, 2012), sömürge dönemi Misırı’nda İslam’ın modern çağlara uyarlanmasını temel alarak 1940'larda hızla geniş kitlelere yayılmıştır. Suriye'de bu karşı çıkış seküler Fransız rejimine karşı gerçekleşecektir (Weismann, 2010: 2-3).

İhvan hareketini diğer İslamcı örgütlenmelerden farklı ve önemli kılan, İslamcılar arasında ilk siyasal talepli örgütlenme olmasıdır (Tekin ve Akgün, 2011: 661). İhvanın toplumsal moral hareketten politik İslami harekete (İslamcılık’a) dönüşümü, Pakistan’n ilk Müslüman-ulus devlet olarak kurulma süreci ve İslam devleti düşüncesinin savunucusu Seyyid Kutub’un ${ }^{9}$ verdiği ilhamla gerçekleşirken (Bulaç, 2011: 46), S. İhvanı’nda bu dönüşüm daha kurulma aşamasında yaşanmıştır. Hinnebusch'un (1982: 152) belirttiği gibi, 1945-46 yllarında Sibai, Suriyéde "İslam devleti” oluşturmak amacıyla yola çıkmış, Şam’daki "Muhammed Gençliği”, Halep’teki “İslam Cemiyeti" ve "Dar'ül Erkam Cemiyeti"ni kuranlarla bir araya gelmiş ve bütün bu cemiyetleri S. İhvanı çatısı altında toplayarak liderliğini üstlenmiştir (Calvert, 2009: 238).$^{10}$ Böylece, S. İhvanı, Suriye'de seküler Fransız rejimine karşı ortaya çıkan İslamcı grupların bu ideoloji çerçevesinde birleşmesi ile oluşmuştur (Weismann, 2010: 2-3). Her ne kadar, Mısır İhvanı’nın etkisiyle kurulmuş olsa da, S. İhvanı, Mısır İhvanı’nın bir şubesi değildir, dünyadaki farklı ülkelerde bulunan İhvanlar da hiyerarşik bir bağa sahip değildir. Dini ideolojiyi, şeriat temelli İslamcı düzeni hedefleseler de örgütlenme açısından her biri kendi ulusal sınırlarında hareket etmiş, yerel koşullarla birbirlerinden farklılaşmışlardır. S. İhvanı, Mısır'dan esinlenmiştir ancak Ömer Faruk Abdullah’n ifadesiyle "Suriye İhvan örgütünün Mısır'dan ithal edildiğini söylemek aldatıcı olacaktır” (Abdullah, 1988: 98). Her İhvan örgütünün kendi ulusal sınırları içerisinde ve kendi koşullarınca evrildiği ve bunun sonucu olarak benzer kökenleri paylaşsalar da farklı stratejiler benimsediği vurgulanmalıdır. Rubin (2010: 10) de Suriye, Ürdün ve Misır İhvanları’nı karşılaştırdığ çalışmasında, bu duruma işaret ederek şöyle demiştir: "Üç grup da köken olarak nasıl paralelse, yerel koşullar nedeniyle ideoloji ve hedeflerde o derece farklıdır." Sonuçta,

\footnotetext{
8 Özellikle bu yönde iddialar Esad rejimi ve PYD Başkanı Salih Müslim tarafından dile getirilmiştir (YDH, 2013). Türkiye’nin S. İhvanı́na koşulsuz desteğine yönelik eleştiri için bkz. Taştekin (2014).

9 Seyyid Kutub hakkında ayrıntılı bilgi için bkz. Shepard (1996).

10 Suriye İhvanı’nın kuruluş dönemi hakkında ayrıntılı bilgi için bkz. Teitelbaum (2004: 134-158).
} 
bulundukları ülkenin koşullarının, siyasal pratiklerinin, harekete sağlanan kamuoyu desteğinin farklıllı̆ı o ülkedeki İhvan’ın ideolojisini, stratejisini ve pratiğini de etkilemiştir.

Politik bir parti gibi çalıştığı ve cemiyet olma özelliğini koruduğu halde S. İhvanı kendisini, bunların her ikisinden ziyade, -tıpkı İslam gibi- hayatın bütün boyutlarını kuşatan ve İslam toplumunun bağrından çıkan bir hareket olarak tanımlar. Sibai’nin şu sözleri bu duruma işaret eder: "Bizim hareketimiz ne bir cemiyet ne de politik bir parti hareketidir. Bizimki İslam ümmetinin bütününü kuşatan bir ruhtur." (Abdullah, 1988: 110-111). Sibai’nin belirttiği bu ruh, temel olarak modern dünyada İslam’ı geniş kapsamlı bir ideoloji olarak açıkça beyan etmeyi amaçlamış, bireyi ve sosyal hayatı bütün yönleriyle içine alan, bütün sorunları çözebilecek olduğuna inanılan İslam Nizamı’na davet etmiştir. Örneğin Sibai’nin önderliğindeki S. İhvanı’nın çalışma programına göre, Suriye’nin sorunlarına İslamcı bir çözüm bulmak, dış güçlere bağımlılığa, feodalizme ve üst sınıfın egemenliğine bir son vermeyi, büyük devletlerin müdahalelerinden korunmayı, milli bir ekonomi yaratmayı gerektiriyordu. (Abdullah, 1988: 113). Bu nedenle S. İhvanı’nın hayatın her alanını kuşatan, her soruna ilişkin "çözüm” sunma iddiasında olan siyasal İslamcı bir hareket olarak ortaya çıktığı görülebilir.

S. İhvanı’nın çoğu lideri, İslam’n Sufî yorumuna -El Bennảnın mirasına- sadık kalmıştır (Abdullah, 1988: 95). Sibai, Muhammed el Mübarek ve Mảruf Davalibi gibi kurucu nesilden düşünürler, 19. yüzyıl ortalarında Şam’a yerleşmiş olan Cezayir'den gelen Sufî ulema ailelerinden gelmiştir (Weismann, 2001: 241-2). İkinci kuşak S. İhvanı́nın önde gelen liderlerinden Said Havva, Baas rejiminin gölgesinde Hama'da yoksul bir çevrede büyümüş, yerel Sufî alimlerden etkilenmiş, Şam Üniversitesi’nde (fakültenin kurucusu ve dekanı Mustafa Es-Sibaidir) şeriat üzerine eğitim almıştır. Havva, Hafız Esad’ın yönetimine İslamcı muhalefetin lider ideoloğu olarak tanınmıştır. Üçü de (Mübarek ve Davalibi Suudi Arabistan'da, Havva Lübnan'da) yaşamlarının son yıllarını sürgünde geçirmişlerdir. Üçüncü kuşak ulema ailesinden avukat Beyanuni, hareketin Halep’teki oluşumunda yer almış ve 1970'lerdeki İslamcı ayaklanmadan sonra liderliğe yükselmiş, 1996 yilında Genel Başkan olmuştur (Shadid, 2005). Son Genel Sekreter, Muhammed Riyad El-Şukfa (Eş-Şakfa/Şükfa/Şukfa), Beyanuni’nin üçüncü dönemini tamamlamasının ardından 2010 yılında seçilmiştir. Babası da Hama'daki topluluğun lideri olan Şukfa, 1960'lardan itibaren hareketin içerisinde yer almış, Suriye rejimine karşı askeri mücadelede önemli görevler üstlenmiştir (Lund, 2010). Yaşamının çoğunu sürgünde, sırasıyla Irak, Yemen ve Suudi Arabistan'da geçirmiştir (Oweis, 2011).

S. İhvanı’nın politik konumlanışını etkileyen unsurlardan biri, kuruluşunun hemen ardından, yasal zeminde temsil firsatını elde etmesidir. S. İhvanı, daha 1946 yılında Suriye Fransa'dan bağımsızlaşırken parlamenter yapıya katılabilmiştir. 1945-63 arasında siyasi parti olarak örgütlenebilmiş, 1949 Darbesi’nden sonra ilk olarak "Sosyalist İslami Cephe"11, ardından “İhvan-ül Müslimin” adlarıyla parlamentoda temsil edilmiştir (Seale, 1965: 79). Her ne kadar parlamentodaki sayıları 10’u geçmese de (1947'de 4, 1949’da 3, 1954’te 5 ve 1961'de 10 sandalye)

11 S. İhvanı, Arap ulusalcılığı ve sosyalizm gibi çağın moda akımlarından etkilenmiştir. 1949'da Sosyalist İslami Cephe adıyla seçimlere girmesinden 10 yıl sonra Sibai, "İslam Sosyalizmi” adlı çalışmasını yayımlamıştır. Bu tutum daha muhafazakar İslamcılar tarafından eleştirilmiştir. Ayrıntı için bkz. Pierret (2012: 72). 
büyük partiler ve bağımsızlar tarafından desteklenmiş, iki üyesi bakan olabilmiştir (Seale, 1965: 182). Özellikle 1947 seçimlerinde hem Komünist Partisine, hem de Baas Partisi'ne oranla daha fazla destek görmüştür. Bu başarının muhtemel nedeni, Abdullah’a göre, "mükemmel bir organizasyona sahip olmanın yanı sıra, program ve adaylarını tanıtmak için camileri, pazarları ve umuma ait diğer yerleri çok etkin bir şekilde kullanmalarıdır" (Abdullah, 1988: 110-111). Bu durum, Baas darbesi sırasında iktidara aday oluşunun temelini ve ertesinde rejim tarafından dışlanmasını açılayan önemli bir unsurdur. Kendini Suriye’de en güçlü grup olarak tanımlayan İhvan yerine, azınlık konumunda görülen Baas'ın ülkede kontrolü eline geçirmesi, yönetim zafiyeti olarak görülmüş ve S. İhvanı içerisinde bölünmeler başlamıştır (Pargeter, 2010: 71). Baas darbesi ve ardından gelen baskı ve sürgünler hareketin bütün unsurlarını derinden etkilemiştir. Başta halka yayılmadaki başarının yerini sürgün ile kamuoyu desteğinin azalmasını almıştır.

S. İhvanı, Lawson’n belirttiği gibi (1982: 24-28), daha çok Sünni, kentli muhafazakar orta sinıftan (din adamları, küçük esnaf ve tüccarlar) destek almıştır. Ancak 1970’lerde Hafız Esad'a karşı İslam’ı araçsallaştıran protestolar geniş tabana yayılmışken bile S. İhvanı’na katılım sınırlı kalmıştır (Weismann, 2010: 3-4). Bunun nedenleri Suriye’nin demografisinde, hareketin "sürgün" konumunda ve bunun getirdiği stratejik unsurlarda, Baas rejiminin baskısı ve $S$. İhvanı içinde yaşanan yönetim zafiyetlerinde aranabilir. İlkin, Suriyẻnin dinsel-etnik yapısı ile birlikte düşünüldüğünde, S. İhvanı’nın Suriye'deki tabanı, nüfusun yalnızca \%60’ına karşılık gelen Sünni topluluklardan ibarettir, kaldı ki, Sünni topluluk da monolitik bir yapıda değildir (Zisser, 2005: 46).

İkincisi, Baas iktidarı döneminde başlayan sürgün, hareketin kamuoyuna ulaşmasını zorlaştırırken, yerel gelişmelerden uzak kalmasına sebep olmuştur. Bu "sürgünde örgüt" konumunun ve ülkede yasaklı oluşunun S. İhvanı̉nın hem kitlesel desteğini hem de örgüt yapısını ve politikalarını belirleyen ana unsur olduğunu söylemek yanlış olmayacaktır. Hareketin ülkede yasaklanmış olması, günümüzde de İhvan’a katılımları sınırlamaktadır. Rubin’e göre (2010: 17), "İslamcıllk için - nihai hedeflerini gizleyerek - daha özgürce örgütlenebilirken, Suriyeliler için S. İhvanı önceki neslin köhne bir örgütü olarak görülmektedir." Kaldı ki, İhvan liderlerinin çoğunun orta yaşlarında olmaları da genç kitle ile aralarında bir diğer mesafeyi oluşturmaktadır (Pierret, 2014: 2). Bu nedenle, kimi Suriyelilere göre İhvan, "geleceğe değil, geçmişe ait bir örgüt" (AlMuqdad, 2014) görünümünde algılanabilmektedir.

Üçüncüsü, hareketin sürgünde ayakta kalabilmesi için benimsediği strateji, kamuoyu desteği sorununu beraberinde getirmiştir. Örgütlenme yapısının sol hareketlerde olduğu gibi katı, hiyerarşik ve gizli olmayıp esnek ve dinamik bir yapıya sahip olması Fulya Atacan’a göre hareketin yıllardır varlğ̆ını sürdürmesinin en önemli sebeplerinden biridir (Atacan, 2011). Bu "esnek"lik S. İhvanı’nda kendini seküler karşıt gruplarla, din adamları ile işbirliği yapması biçiminde kendini gösterir (Talhamy, 2012: 33). ${ }^{12}$ Ancak hareketin sürgünde bile ayakta kalabilmesini sağlayan bu durum, kamuoyu desteği açısından S. İhvanı’nın ana hedeflerinin ne olduğu konusunda belirsizlik ve güvensizlik yaratmış, sonuç olarak hareketin sürekliliğini sağlarken, kitlesel desteğini azaltmıştır.

12 Belirtildiği üzere, S. İhvanı’na üye olmak için gereken resmi ölçüt, Suriyeli olmak ya da Suriyede ikamet etmektir (Haffar, 2013). 
Son olarak Hafız Esad’n ulusal birliğin ve iktidarın konsolidasyonun sağlanması için rejiminin güvenliğini tehdit edecek her tür muhalefeti bastırma politikası, başta S. İhvanı olmak üzere ülke içindeki muhalif oluşumlara yönelik uygulanan sindirme politikasını beraberinde getirmiştir. Seküler nasyonalist Baas Partisi, S. İhvanı ve onu destekleyen yerel Sünni esnaf sınıfını güçsüzleştirmiş, rejimin yeni burjuvazi yaratma politikası sonucunda ${ }^{13}$ teşviklerden yeterince yararlanamadığını düşünen geleneksel ticari burjuvazinin S. İhvanı’na finansal ve moral destek vermesi sonucunu doğurmuştur. Bu durum özellikle ülkenin kuzeyinde Hama, Halep gibi büyük kentlerde örgütlenmelerinin önünü açmıştır (Lawson, 1992: 131).

Sünni çoğunluğun, az çok iktidardan dışlanmaya başladığı 1950'li yıllardan itibaren S. İhvanının radikal kanadının oluşmaya başladığı söylenebilir (Demant, 2006: 105). Özellikle Baas iktidarı döneminde bu radikalleşme hız kazanmıştır. S. İhvanı, Sibai’nin ölümünün ardından 1957 yllında liderliğe gelen İsam El-Attar’’n döneminde başlayan yönetim zaafları nedeniyle radikal/ şiddet yanlısı kanadı ile bağlarını kesememiştir (Pargeter, 2010: 67). Rubin’e göre (2010: 12), hareketin silahlı bir direnişi deneyip başarısız olması günümüzde barış̧ı seçeneklerden yoksun kalmasının sebeplerinden biridir. Esad'ın 1973’teki laik anayasa girişimi ile S. İhvanı́nın Baas rejimine karşı ayaklanması ivme kazanmış, rejimin seküler uygulamaları ve Attar’n politikası, harekette bölünmeye yol açmıştır. Attar yanlılarının karşısında, Hama’da Seyyid Kutub’un arkadaşı ve düşüncelerinin savunucusu Mervan Hadid ön plana çıkmıştır. ${ }^{14}$ Radikalleşme çerçevesinde S. İhvanı’nın tarihinde iki önemli gelişme belirleyici olmuştur: Baas Darbesi ve Hama Olayları. ${ }^{15}$

\section{Suriye İhvanı’nın Aşamalı Sürgünü}

S. İhvanı’nın, kendini ülkede en önemli politik güç olarak tanımladığı dönemde Baas Darbesi’nin gerçekleşmesi, örgüt içerisinde sorgulamalara neden olmuş, katı bir Selefi inanışına sahip olan Attar’ın, Selefilik ${ }^{16}$ dışındaki akımları hareketten dışlaması, Örgütün tabanında ayrışma yaratmıştır. Tarikat ve ulemanın desteğini yitiren Attar’ın silahlı mücadeleye karşı oluşu ise, dinamik genç kitleyi hareketten soğutmuştur. Darbenin hemen ardından, S. İhvanı’nın yasadışı ilan edilmesi ve Attar’ın sürgüne yollanması ile yaşanan liderlik bunalımı iyiden iyiye gün

${ }^{13}$ Bu konuda daha detaylı bilgi için bkz. Atlıoğlu (2006: 52-60).

14 S. İhvanı, Hadid ile ilişkisine mesafeli yaklaşmakta ve üyelikten çıtığını belirtmektedir. Haffar’ın anlatımıyla, Hadid’e iki seçenek sunulmuştur: şiddeti bırakması ya da S. İhvanı’ndan ayrılması. Hadid kendisi ayrılmayı seçmiştir (Basil Haffar ile görüşme, 4 Kasım 2013, Fatih.) Hadid, 1963’ten 1970’e değin Suriye’nin önde gelen din adamlarının desteğini alarak Baas rejimine karşı açıktan mücadeleye girişmiştir. Hama ekibine yakın Said Havva, Şeyh Abdülfettah Ebu Gudde, Adnan Saadettin gibi liderlerin silahlı mücadeleyi savunan "İslam devrimi için silaha sarılmak, kâfir rejimi ortadan kaldırmak için zafere kadar cihat etmek gerektiği...” şeklindeki görüşleri güç kazanmıştır. (Van Dam, 2000: 47.) Ancak Said Havva gibi sempazitanlarının olmasına rağmen, Hadid ve taraftarları S. İhvanı’ndan doğrudan yardım almamış ve onun onayını görmemiş, örgütün dış kısmında küçük bir hareket olarak kalmıştır.

15 Baas Partisi hakkında detaylı bilgi için bkz. Ben-Tzur (1968) ve Rabinovich (1972).

16 Selefi, İslam’ı anlamada ve yaşamada ilk nesil Müslümanları olan Selef'in takipçisi demektir. Genellikle Kuran'dan ve Sünnetten sapmalar olduğu iddiasıyla geleneksel mezhepleri reddederler. Selefilik hakkında detaylı bilgi için bkz. El-Kusi (2010). 
yüzüne çוkmıştır. Bu dönemde Attar'n sürgünde yönetime devam etme arzusu örgüt içerisinde rahatsızlı̆̆ artırmış, liderlik bunalımı 1971'de Ürdün, Mısır, Körfez Ülkeleri ve Sudan'daki İhvan temsilcilerinin arabuluculuğu ile aşılmaya çalışılsa da, 1980 sonlarında Suriye İslam Cephesi'nin kuruluşuna kadar tam olarak giderilememiştir (Abdullah, 1988: 131-2).

S. İhvanı’nın 1980 Haziranı’nda Hafız Esad’a yönelik suikast girişiminden sorumlu tutulması (Bidwell, 2010: 289) sonucunda 7 Temmuz 1980 tarihinde 49 Sayllı Kanun kabul edilmiştir. Kanun’un ilk maddesi "İhvan-1 Müslimin örgütüne üye olan her kimse suçludur ve idam cezası ile cezalandırılır” hükmündedir (Wright, 2008: 248). Buna karşılık S. İhvanı Aralık 1980'de gelecekte Suriye'de kurulacak olan İslam Devletỉne ilişkin detaylı bir program içeren manifesto yayımlamış, Şam’n dışındaki kent merkezlerinde ve Hama'da gizli çalışmalarına devam etmiştir. Her ne kadar S. İhvanı silahlı yeraltı örgütlerle bağlantısını inkar etmiş olsa da, iddialar ciddiye alınmamış, İslamcı muhalefeti ortadan kaldırmak üzere şiddeti artıran yönetim o dönemde birçok S. İhvan mensubunu idam ettirmiştir (Dekmejian, 1995: 109). Bu şiddetin en önemli örneği "Hama Katliamı" olarak adlandırılan 2 Şubat 1982 tarihinde Hama kentinde on binlerce insanın öldürmesi ve ikinci kuşak liderlerin sürgün edilmesidir (Middle East Watch, 1991: 17-20).

Hama olaylarının ardından S. İhvanı birçok yönde değişim geçirmiştir. 1960'lı yıllardan itibaren aşamalı olarak yönetici kademenin yurtdışına çekilmesi, 1980'lerden sonra ise topyekûn sürgüne uğraması sonucunda S. İhvanı, siyasal coğrafyasını değiştirmiş, taleplerini uluslararası platformda dile getirmeye başlamıştır. Hareketin uluslararası boyuta taşınması sonucunda, $A B D$ ve İsviçre'de "Hürriyetlerin ve Suriyedeki Siyasi Tutukluların Savunulması İçin Birlik" adlı dernekler kurulmuş, Arapça, İngilizce, Fransızca, Almanca ve İspanyolca dillerinde yayınlanan "El-Minber" dergisi S. İhvanı́nın Suriye devleti ile mücadelesini uluslararası kamuoyuna yansıtmış, birçok ülkede S. İhvanı hakkında yayımlar yapılmışıır. ${ }^{17}$

Sürgünün ardından örgütün söylemlerinde Batı karşıtlığı ve modernizm eleştirisi, S. İhvanı Batı'da yaşama durumunda kaldığı için arka plana itilmiştir. ÇünküS. İhvanı’nın karşı olduğu Suriye rejimidir, hedef ise rejimi dönüştürmek/değiştirmektir. Başlangıçta Fransız sömürgeciliğine bir tepki olarak gelişen hareketin Batıya taşınması ideolojisinde Batı karşıtı yönün törpülenmesine neden olmuştur. Daha fazla demokrasi vurgusu taşıyan söylemlerin yoğunluk kazanması, 80’li yıllarla birlikte artmıștır. Ancak bu demokrasi anlayışı İslamcılık ile birlikte ve ona bağlı olarak biçimlenmiş, "Her dine karşı hoşgörü" vurgusu Kur'an'dan ayetlerle desteklenmiş, böylece demokrasi, İslamcllık ile bağdaştırılmaya çalışılmıştır. Bu durum o dönemde yayımlanan siyasi programlarında kendini gösterir. "Suriye İslam Devrimi Programı́nın İlanı" ve "Suriye İslam Cephesi Şartı” adlı metinlerinde S. İhvanı, “...halkımızın başına gelen en büyük baş belası İslam alanından çıkarılması, özgürlüklerini kaybetmesi ve toplumun tüm kesimlerinin baskı ve zorlama ile boyunduruk altına alınarak kendine ait iradesi olamayan bir koyun sürüsüne dönüşmesidir" tespitini yapar (Weismann, 2010: 11). Çözüm için ise "eşitlik, yaşama hakkı ve onuru, doğrudan seçimler, azınlık haklarının korunması gibi anayasal prensiplerle, siyasi tutuklamaların askıya alınmasını ve güçler ayrımına, düşünce, ifade ve örgütlenme özgürlüğüne dayalı Şuranın

17 Örneğin Türkiye’de de Milli Gazete 28 Şubat 1987 tarihli sayısında "Hama" adlı bir ek yayımlayarak Hama olaylarına ilişkin detaylara yer vermiştir (Baban, 2006: 102). 
yönetimi”ni vaat eder (Weismann, 2010: 11). Suriye toplumu 20 yll öncesine kıyasla dini değerleri ön plana çıkardıkça, Suriye İhvanı’nın söylemde sekülerleşmesi ilgi çekicidir. 2000’li yıllarla birlikte muhalefetle hareket ederek, farklı unsurlarla bir araya geldikçe S. İhvanı’nın söyleminde bu ifadeler daha fazla yer almıştır. 2002'de Londra'da gerçekleştirilen konferansın sonucunda yayınlanan bildiride hareketin amacının açıklandığı kısımda bu durum şöyle görülebilir:

"Modern Suriye’yi kurmak: Çoğulculuğa ve güçler ayrımına dayanan; hukukun üstünlüğü, adalet ve eşitliğin sağlandığı; insan haklarının garanti altına alındığı, onurun korunduğu ve yurttaşların ulusal kararlara etkin katılımı ile kamu yararını paylaştı̆̆ı sivil ve siyasi haklarından memnun olduğu bir devlet" (Salem, 2002).

2004 ylında açıklanan "Suriye’nin Geleceği İçin Siyasi Proje”de, Suriyede oluşturulacak çoğulculuk, insan hakları, eşitlik, adalet, sivil toplum ve yasal yönetime dayalı politik yapı için bir program yayımlanmıştır (Ghadbian, 2010). Programda, hükümetin parlamentodan biçimlenerek ona karşı sorumlu olacağı ve yasamanın çok partili genel seçimlerle oluşacağı belirtilmiştir. Ancak siyasi programında yasa yapımında seçimle oluşmamış "uzmanlar"a tanımlanmayan bir rol vermesi, din adamlarının yasama sürecine katılımının temelini oluşturabilir. Pierret'ye göre (2012: 77), S. İhvanı bu programla her ne kadar ideal devletini "sivil" ve "teokratik olmayan" biçiminde tanımlasa da, "yasaların aşamalı İslamlaşması" yoluyla "İslamcı devlet"i kurma hedefinden vazgeçmemiştir.

$\mathrm{Bu}$ "sürgünde örgüt" konumu, hareketin strateji ve taktiklerini de biçimlendirmiş, öncelikli hedefler konusunda dönem dönem manevra alanını daraltmıştır. Rejimi değiştirmek/ dönüştürmek ile sürgündeki/hapisteki üyelerin özgürlüguünü/yurda dönüşünü sağlamak gibi amaçlar konjonktüre bağlı olarak yer değiştirmiştir. Rejimle ılımlı ilişkiler kurulabildiğinde baskıyı sonlandırma/hapisteki üyelerin özgürlüğünü sağlama öncelikli iken, konjonktürel şartlar elverdiğinde rejimi değiştirme/dönüştürme birbiri yerine geçmiştir. Bunun en açık örneği, Beyanuni’nin yönetimi ile S. İhvanı’nda yaşanan yeni dönemde görülebilir. Hafız Esad iktidarını devirerek rejimi değiştirme amacını gerçekleştirmenin zorluğu ile S. İhvanı, öncelikle rejim ile uzlaşma ve sürgün/hapisteki S. İhvanı üyeleri için çözüm bulma çabasına girmiş, Beşar Esad döneminde görece yumuşama ve kısmı af elde edebilmiştir. Bu yumuşamanın arka planında, uluslararası sistemde yaşanan değişimin etkisi de olabilir. 2000'li yıllardan itibaren Sovyet desteğinden yoksun kalan Suriye/Baas iktidarı ve yönetimi yeni devralan Beşar Esad, toplumsal uzlaşma amacıyla ilk başlarda S. İhvani’yla anlaşma yoluna gitmiştir. Beyanuni öncelikle rejim ile uzlaşma ve sürgün/hapisteki üyeleri için çözüm bulma çabasına girişmiş, şiddeti reddettiğini ve Esad rejimini tanıdığını açıklamıştır. Esad’ın Beyanuni’nin 3 temel isteğini (bütün S. İhvanı üyelerinin hapisten çıkarılması, sürgündekilerin ülkeye dönüşüne izin verilmesi ve hükümetin $S$. İhvanı́na yönelik yasaklamaları kaldırması) reddetmesi, Beyanuni’nin demokratik söylemlerinde bir değişim yaratmasa da stratejik bir farklılığa neden olmuş, S. İhvanı bu kez rejimi dönüştürme hedefine yönelmiştir. Kamuoyu desteğinin yetersizliği, sürgünde oluşunun verdiği kıstlllık ile $S$. İhvanı, farklı birçok unsurla birlikte hareket etme durumunda kalmıştır. Bu esneklik hareketin ayakta kalmasını sağlarken, kitlesi nezdinde sorgulamalara neden olmuştur. Örneğin, Beyanuni’nin isteklerinin rejim tarafından karşılanmaması üzerine, S. İhvanı, liberaller, komünistler, Kürtler ve 
hatta iltica eden eski Başkan Yardımcısı Abdulhalim Haddam gibi seküler muhalefet ile güçlerini birleştirmeye çalışmıştır. Sibai'nin büyük devletlerin müdahalesinden korunma ve milli ekonomi yaratma hedefi, Suriye içerisindeyken rejimi dönüştürme amacıylaydı. Sürgünde iken, örgütün yurda dönüşünün sağlanması, böylece ayakta kalabilmesi öncelikli hale gelmiştir.

\section{Suriye Muhalefetinde Suriye İhvanı}

2005’teki Lübnan Eski Başbakanı Refik Hariri suikastına Suriye rejiminin karıştığı iddiaları ile ${ }^{18}$ Suriye içinde muhalefet hareketlenmiş, 2005 Ekimi’nde Suriyeli muhaliflerin yayınladığ "Ulusal Demokratik Değişim İçin Şam Deklarasyonu" ülke içinde yeni dalganın oluşması yönünde ümitler doğurmuştur. S. İhvanı, bu hareket içerisinde etkin olarak yer almış, bu bileşim Mart 2006'da Ulusal Kurtuluş Cephesỉne (NSF) dönüşmüştür. Bu muhalefetin içerisinde S. İhvanı̉nın konumunu incelemek, günümüzde Suriye Savaşı’ndaki durumu değerlendirmek için açıklayıcı olabilir.

Suriye muhalefeti içerisinde S. İhvanı'nın konumunu belirleyen birkaç unsurdan bahsedilebilir. Öncelikle "sürgünde örgüt" konumunun getirdiği kamuoyuna ulaşmadaki yetersizlikler S. İhvanı'nın tek başına muhalefeti yüklenmesi bir kenara muhalefet içerisinde etkin bir konumda olmasını bile engellemiştir. Ancak uzun zamandır sürgünde de olsa, muhalif koalisyonun özellikle yurtdışında oluşumunda önemli bir rol oynamıştır. (Pierret, 2012: 71).

İkinci olarak S. İhvanı’nın kendi içerisinde yaşadığı sıkıntılar, hedef sapmaları, muhalefet içerisindeki konumuna da doğrudan etki etmiştir. Önceki bölümde belirtildiği gibi, rejimi değiştirme/dönüştürme ile yurda dönebilme hedeflerinin konjonktürel olarak birbiri yerine geçmesi, diğer muhalif unsurlar arasında S. İhvanı’na duyulan güvenin sorgulanmasına yol açmıştır. Birçok sekülarist ve azınlık grup S. İhvanı’nın muhalefet içerisinde Sünni bir blok yaratmaya çalıştığı eleştirisinde bulunmuştur (Lund, 2011). S. İhvanı̉nın bu blok içerisinde konumunun, ne kendi kitlesi tarafından, ne de muhalefet cephesi tarafından pek kabul görmediği söylenebilir. Eski rejimin isimlerinden Haddam’ın muhalefet içerisindeki konumu S. İhvan'ında tartışmalara neden olmuştur. George Rabil (2010: 85-86), Haddam’ın katılımını şöyle yorumlamışır: "Haddam’n rejimin zulmü ile birlikteliği hala muhalefetin zihninde tazeyken, İhvan muhalefet saflarındaki kronik çatlakları yeniden açmıştır." Haddam’ Baas rejiminin uzantısı olarak gören S. İhvanı üyelerinin tepkisine yönelik olarak Beyanuni şu açıklamayı yapmıştır:

“Biz Şam Deklarasyonu üyeleriyiz ve Ulusal Kurtuluş Cephesi üyeleriyiz. Ulusal Kurtuluş Cephesi'ne üye olmak, başka bir cephe ya da birliğe üye olmakla çelişmez... Şu anda ülkede demokratik değişimin yaşanması için barışçı muhalefetin içerisindeyiz ve ulusal gruplarla ortak olmak istiyoruz" (Syria Monitor, 2006a).

18 Hariri suikastı hakkında bir değerlendirme için bkz. Rubin (2010: 206-210). 
Beyanuni’nin açıklamasından da görülebileceği gibi, S. İhvanı (yurda dönebilmek ve demokratik değişimi sağlamak gibi amaçlarına ulaşabilmek -çelişkili de olsa- için farklı unsurlarla işbirliği yapmak durumunda olduğunu kabul etmektedir. Kaldı ki, S. İhvanı, 2006 İsrail-Hizbullah çatışmasında bir kez daha yön değiştirerek, Suriye ve Hizbullah Arap dünyasında takdir kazanmış; Beyanuni’nin açıklaması doğrultusunda rejim aleyhtarı faaliyetlerini geçici süre ile dondurmaya karar vererek, , muhalefetten çekilmiştir (Syria Monitor, 2006b). Bu, S. İhvanı’nın Suriyeye dönebilme umuduyla gerçekleştirdiği stratejik bir manevra olarak değerlendirilebilir. $\mathrm{Bu}$ dönemden sonra S. İhvanı, rejimle anlaşma amacıyla bir süre bekleme kararı almıştır. Kasım 2009'da yapılan röportajda Beyanuni şöyle demiştir: "Bazı arabuluculara rejim tarafından verilmiş kimi olumlu sözler var. Biz bunları hoş karşılıyor ve hala hareket bekliyoruz. Şu ana kadar hiçbir şey değişmedi ve bu gösteriyor ki sorun rejimde bizde değil” (Talhamy, 2012: 38).

Arap isyanlarının etkileri bölgede iyice hissedilmeye başladığı sırada, ılımlı Beyanuni’nin yerine Muhammed Riyad El-Şukfa Temmuz 2010'da genel başkanlığa getirilmiştir. Böylelikle, S. İhvanı’nı yeniden ve daha keskin biçimde muhalif kanada geçmiştir. 1960'lı yılların başından itibaren S. İhvanı’nda yer alan Şukfảya göre, kendileri ve Suriye rejimi arasında birçok arabuluculuk girişimi olmuş, ancak hepsi rejimin S. İhvanı’na dönük sınırlamaları kaldırmayı reddetmesi nedeniyle başarısız olmuştur (Milliyet, 2011).

Beyanuniden daha muhalif bir tutum içerisinde olan Şukfa yönetimi devraldıktan sonra rejim karşıtı hareketlere devam edileceğini açıklaması, S. İhvanı içerisinde sorunlara neden olmuştur. Örneğin, eski MK lideri Said Havvảnın oğlu olan Muhammed Said Havva, S. İhvanı’na mektup yazarak, rejimle ilişkiler konusunda bir yol haritası önermiştir. Buna göre, S. İhvanı rejimin önerdiği bazı üyelerin geri dönmesine izin vermesi ile yetinmelidir. Ayrıca Havvàya göre rejim tarafından verileni ikili görüşmeler için bir başlangıç olarak kabul ederek sonrasında başka istekler sunulmalıdır (Talhamy, 2012: 38). Buradan da görülebileceği gibi, S. İhvanı kendi kitlesi içerisinde bile bir bütünlüğe ulaşamamıştır. Bu örgüt içi tartışmalar, S. İhvanı’nın daha temkinli bir politikaya yönelmesinin nedenlerinden biri olabilir.

Mart 2011 itibariyle, gösteriler yoğunlaşmış, her ne kadar S. İhvanı açıkça protestoculara desteğini vurgulasa da örgütlediğini kabul etmemiştir. Protestoculara yönelik şiddet sona ererse rejimle diyaloğa gireceklerini açıklamışlar ancak birleşik bir hareket yaratmak için toplantılara devam ederken benzer bir çekinceyle hareket etmişlerdir. Mayıs 2011'de Antalya'da düzenlenen konferansta S. İhvanı temsilcileri, "varlıklarının açılış seremonisinden sonra olduğunun" altını çizmeye özen göstermiştir (Sly, 2011). Ekim 2011'de S. İhvanı ve yedi karşıt grubun katılımı ile Suriye Ulusal Konseyi (SUK) oluşturulan Konsey’in içerisinde S. İhvanı’nın ağırlı̆̆ı yine tartı̧̧malıdır. Bir değerlendirmede, "muhaliflerin önemli bir bölümünü çatısı altında toplayan SUK'un 310 üyesinin yaklaşı dörtte birinin S. İhvanı ile bağlantıll” olduğu söylenmektedir (Frenkel, 2012). S. İhvanı, her ne kadar iki dönemdir başkanlığını laik ve liberal bir Batı yanlısı olan Burhan Kalyon'un yaptığı SUK'un bir parçası olsa ve bu konseyde temsilcileri bulunsa da, muhalefet içerisinde pozisyonunu, "örgütleyici değil katılımcı" olarak açıklamaktadır (Hassan, 2013). Bu duruma uyan biçimde, Konsey'in liderliğini üstlenmemiştir. Ancak Konsey’in yaptığ 1 Batı yanlısı açılamalar da S. İhvanı tarafından reddedilmemiştir. 
Sonuçta, SUK içinde fazla aşırı unsurları barındırmasına karşılık kapsayıcı olmadığı gerekçesi ile uzun ömürlü olamamış; yerine daha seküler yeni bir şemsiye örgüt, Suriye Muhalif ve Devrimci Güçler Ulusal Koalisyonu (SMDK) kurulmuştur. S. İhvanı da ABD’nin ve Katar'ın isteği ile Dohảda başlayan muhalefet arayışı toplantılarına aktif olarak katılmıştır (Zeyrek, 2012). SMDK uluslararası meşruiyet kazanarak $A B D$ ve $A B$ tarafindan tanınmıştır. Arap Birliğinde de tanınma elde ederek, Mart'taki toplantısında Suriye’ye ait koltuğu devralmıştır (Radikal, 2013a). Ancak muhalifler arası bölünmeler artarken, bu durum S. İhvanı’nı da etkilemiştir. SMDK tarafından oluşan geçici hükümete Başkan olarak Ghassan Hitto seçilirken, bazı S. İhvanı üyelerinin "Hitto bize dayatıldı" diyerek seçime katılmadıkları basına yansımıştır (Milliyet, 2013). Muhalifler içerisindeki çatışmanın bir göstergesi de, Suriyèye ulaşan yardımların paylaşımında ortaya çıkmıştır. Özgür Suriye Ordusu militanları şöyle demiştir: "S. İhvanı Suriyede daha fazla rol almak istiyor ve bu gemi yüküne el koyarlarsa bunun yardımı olacağını biliyorlar" (Radikal, 2012). Bir anlamda, Esad sonrası kurulması planlanan düzende muhaliflerin bir birlik olamadığı, ancak grupların pozisyonlarını güçlendirmeye çalıştığ gözlemlenmektedir. Bu oluşumlar içerisinde S. İhvanı’nın pozisyonunu anlamak için Şukfảnın şu açıklamalarına bakılabilir:

\begin{abstract}
"Bizim politikamıza bakılırsa, bizler vatana hizmet eden bütün ittifaklara katılıyoruz... Tabi Konsey'de bazı hatalar olmuştu, ancak bu demek değil ki Konsey hiçbir olumlu rol oynamadı... yeni kurulan "Ulusal Koalisyon” çatısı altına Ulusal Konsey olarak girmeyi başardık. Biz bu ittifakı destekliyoruz ve rolünün daha aktif şekilde genişlemesi için çalışıyoruz. Tabi Ulusal Konsey ve Ulusal Koalisyon olarak bu rejimle hiçbir şekilde müzakerelerin yapılmaması ve rejimin yıkılması için her türlü desteği vereceğimizi açıkladık. Bazı taraflar rejimle müzakereye girilmesini istemektedir. Onların bu ittifak içinde yeri yoktur” (Orhan, 2012).
\end{abstract}

$\mathrm{Bu}$ gelişmeler yaşanırken, Mısır'da iktidarda bulunan İhvan’n askeri darbeyle yönetimden alınması Suriyeyi de etkilemiştir. Suriye Erformasyon Bakanı Ümaran El-Zubi, Mısır Cumhurbaşkanı Mursi ve İhvanı’ı devleti yönetemediklerinin bir kez daha kanıtlandığını ifade ederken; Esad da, bunu “Politik İslam’ın sonu” biçiminde değerlendirmiştir. (Aji, 2013).

Son olarak, Suriye'de savaşa çözümü arayan Cenevre görüşmelerinde muhalefet ve rejim bir araya gelmiş, ancak Esad rejiminin geçiş hükümeti kurulması konusunu konuşmayı reddetmesi nedeniyle sonuçsuz kalmıştır (Hürriyet, 2014). Kısacası, Esad'ın devlet başkanı olarak kalmaya devam edeceği (CYBC, 2013), hatta Haziran'da yapılması beklenen başkanlık seçimlerinde de aday olacağı (Son dakika, 2014) açıklamaları, savaşın daha uzun bir süre devam edeceğini göstermektedir.

Özetle, S. İhvanı her ne kadar modern yüzünü ön plana çıkarsa da, demokrasi ve insan hakları konularında Pargeter'ın (2010:102) deyimiyle, İhvan'ın "herkesi ikna etmede uzun bir yolu olduğu" söylenebilir. Muhalif ittifaklarla kendini sağlamlaştırmaya çalışan S. İhvanı hem Suriyelilere hem de dünyanın geri kalanına güvenilir olduğunu göstermeye daha fazla çabalamalıdır. 


\section{Sonuç Yerine}

S. İhvanı’nı tanımayı, politik konumunu ve muhalefet içerisindeki durumunu anlamayı amaçlayan çalışmada, varılan birkaç sonuçtan bahsedilebilir. S. İhvanı’nın, İslamcı örgütlenmeler için Calvert'in tanımladığı gibi, Müslüman birikimin uzun süreli reddedilişine bir tepki olarak Suriye'de kurulduğu görülmüştür. Buradaki reddedilişe tepki, özellikle 1973’teki laik anayasa girişimi ile ivme kazanmış, bu noktadan sonra S. İhvanı’nın radikal kanadı güçlenmiştir. Mevcut rejimin seküler uygulamalarının, S. İhvanı’nın İslamcı yönünü pekiştirdiği söylenebilir.

S. İhvanı’nın tarihini ve tutumlarını belirleyen en önemli olgu, ilk başlarda geniş kitle desteği almasının ardından hareketin bir süre sonra yurtdışına taşınmak durumunda kalmasıdır. İlk başlardan itibaren İslam Devleti kurmak amacında olan S. İhvanı, parlamento ve hükümette temsil edilmiş; Baas rejimi ile ise güç kaybetmiştir. Bu durum, bir yandan yerel gelişmelerden uzak kalmasına, kendi kitlesi nezdinde sorgulanmasına neden olurken; diğer yandan Batı’ya dönük bakışını ve ideolojisi ile stratejini yeniden biçimlendirmiştir. İlk başta Fransảnın sömürgeciliğine bir tepki olarak gelişen S. İhvanı, liderlerinin aşamalı sürgünü ile Batıya taşınmış, bu durum ideolojisinde Batı karşıtı yönün törpülenmesine neden olmuştur. Daha fazla demokrasi vurgusu taşıyan söylemlerin yoğunluk kazanması, 80’li yıllarla birlikte artmıştır. Ancak bu demokrasi anlayışı İslamcılık ile birlikte ve ona bağlı olarak biçimlenmiştir. "Her dine karşı hoşgörü" vurgusu Kur’an'dan ayetlerle desteklenmiştir. Bu "sürgün" hâli, öncelikli hedefler konusunda da dönem dönem Örgüt'ün manevra alanını daraltmıştır. Rejimi değiştirmek/dönüştürmek ile sürgündeki/ hapisteki üyelerin özgürlüğünü/yurda dönüşünü sağlamak konjonktürel olarak ön plana çıkmıştır. Rejimle anlaşma çabaları sürerken baskıyı sonlandırma öncelikli hedefleri iken, bu olmadığında ve konjonktürel şartlar elverdiğinde rejimi değiştirme/dönüştürme birbiri yerine geçmiştir.

$\mathrm{Bu}$ "zor şartlar altında ayakta kalabilme" pratiği Örgüt'ün farklı grupla ittifak yapma pratiği edinmesini sağlamıştır. Daha ilk kurulduğu yıllardan itibaren, S. İhvanı radikal kanadı oluşmuş; Baas iktidarı ile radikalizm hız kazanmıştır. 1970'li yıllarda İsam El-Attar dönemindeki liderlik krizi, cihat yanlısı Hadid'i ön plana çıkarmış, yaşanan şiddet 1982'deki Hama katliamı ile zirve noktasına varmıştır. Bu olay sonucunda Suriyede hareket olanağı bulamayan S. İhvanı, uluslararası platformda taleplerini dile getirmeye başlamıştır. Bundan böyle öncelikli hedef, yurtdışında sürgünde olan S. İhvanı üyelerinin yurda dönüşünü, hapisteki üyelerin serbest bırakılmasını sağlayabilmektir.

Rejimi değiştirme hareketinde S. İhvanı lider pozisyonunu sergilememeye dikkat ederek, katılımcı olduğu vurgusunun altını çizmiştir. Ulusal gruplarlar ortak olmak, katliam ve şeriat dayatması yapmamak söylemlerinde öncelikli sırada yer almıştır. Bu pozisyon, S. İhvanı’nın diğer muhaliflerle birlik olabilme, bu farklı grupları kendi üyelerine açıklamayabilme fırsatını da sağlamıştır. Uluslararası sistemde Esad'ın yeniden kabul görmeye başlaması, S. İhvanı’nın arabulucularla rejimle uzlaşısı önünü açıp onu bir kez daha "bekleme" sürecine geri döndürse de, Arap isyanları ve Şukfảnın liderliği ile bu dönem sona ermiştir. Muhalif hareketlerle birlikte rejime son verme amacında olan S. İhvanı, artık Esad'la görüşmeyi reddetmekte, siyasi olarak partileşmeyi planlarken muhalif bütün unsurlara kapılarının açık olduğunu vurgulamaktadır. 
Suriye'deki gelişmeler çerçevesinde son dönemde SMDK uluslararası alanda tanınırlı̆̆ını artırırken S. İhvanı bu koalisyon içerisinde yerini korumakta, bir yandan da siyasi parti hazırlıkları yapmaktadır. Şu anki verilerle, S. İhvanı'nın Suriye'nin geleceğinde önemli bir aktör olacağı öngörülebilir. Şukfa'nın açıklamalarına bakılarak "rejim yıkıldıktan sonra" S. İhvanı’nın daha aktif liderlik rolünü benimsemeye çalışabileceği söylenebilir. Ancak Suriye toplumu tarafından ne kadar kabul göreceğinin yanı sıra uluslararası alanda ne kadar destek sağlayabileceği de belirsizdir. 


\section{Kaynakça}

Abdullah, Ö. F. (1988) Suriye Dosyası, Akabe Yayınları, İstanbul.

Aji, A. (2013) “Assad Applauds Fall of Egypt’s Muslim Brotherhood” [çevrimiçi], Times of Israel, http://www. timesofisrael.com/assad-applauds-fall-of-egypts-muslim-brotherhood/ [Erişim tarihi: 21.01.2014].

Akçura, Y. (2011) Üç Tarz-1 Siyaset, Kilit Yayınevi, Ankara.

Akdoğan, Y. (1999) İslamcılık Bağlamında Türkiye’de Siyasal İslam’ın Gelişimi ve Refah Partisi, Yayınlanmamış Doktora Tezi, Marmara Üniversitesi Sosyal Bilimler Enstitüsü, İstanbul.

Al-Muqdad, O. (2014) Suriyeli gazeteci Omar Al-Muqdad ile mülakat, mülakatı yapan: B. Gürpınar, 4 Kasım, Taksim, İstanbul.

Atlığlu, Y. (2006) Beşşar Esad Suriyesinde Reform, Tasam Yayınları, İstanbul.

Atacan, F. (2011) “Fulya Atacan'la Arap Baharı Üzerine Söyleşi”, Praksis, 26 Şubat.

Baban, İ. T. (2006) Müslüman Kardeşler Örgütünün Çağdaş İslamcı Akımlar Üzerindeki Etkileri, Yüksek Lisans Tezi, T.C. Gazi Üniversitesi Sosyal Bilimler Enstitüsü Uluslararası İlişkiler Anabilim Dalı, Ankara.

Ben-Tzur, A. (1968) “The Neo-Ba'th Party of Syria”, Journal of Contemporary History, 3: 161-181.

Bidwell, R. (2010) Dictionary of Modern Arab History, New York: Routledge.

Bulaç, A. (2011) “İslam’ın Üç Siyaset Tarzı veya İslamcıların Üç Nesli”, Modern Türkiye'de Siyasi Düşünce Cilt 6, İslamcılık, İstanbul: İletişim Yayınları, 48-68.

Bulut, F. (1994) İslamcı Örgütler, İstanbul: Tüm Zamanlar Yayıncılık.

Calvert, J. (2008) Islamism: A Documentary and Reference Guide, Wersport: Greenwood Press.

Calvert, J. (2009) Sayyid Qutb and the Origins of Radical Islamism, New York: Columbia University Press.

Canatan, K. (1995) “Bir Okuma Biçimi Olarak Fundamantalizm ve İslamcılık”, Bilgi ve Hikmet, 12(Güz): 50-52.

CYBC (2013) "Suriye Enformasyon Bakanı: Beşar Esad Suriye Devlet Başkanı olarak kalmaya devam edecek” [çevrimiçi], http://www.cybc.com.cy/tr/index.php/uluslararas-haberler/item/6313-d [erişim tarihi: 17.02.2014].

Çağlayan, S. (2010) Müslüman Kardeşler'den Yeni Osmanlılar’a İslamcılık, İstanbul: İmge Kitabevi.

Çakmak, C. (2007) “Müslüman Kardeşler Bir Sivil Toplum Örgütü Mü?”, Akademik Orta Doğu, 2(1): 69-98.

Dekmejian, R. H. (1995) Islam in Revolution: Fundamentalism in the Arab World, Syracuse: Syracuse University Press.

Demant, P. (2006) Islam vs. Islamism: The Dilemma of the Muslim World, Westport: Praeger Publishers.

El-Kusi, M. B. S. (2010) Selefilik, İstanbul: Guraba Yayınları.

Esposito, J. L. (1998) Islam and Politics, New York: Syracuse University Press.

Frenkel, S. (2012) “Syrian Rebels Squabble Over Weapons As Biggest Shipload Arrives From Libya”, Times, 14 Eylül.

Ghadbian, N. (2010) “Syria’s Muslim Brothers: Where to Next?” The Daily Star, Beirut, 17 Eylül.

Göle, N. (1991) Modern Mahrem, İstanbul: Metis Yayınları.

Gülenç, K. (2011) “Küreselleşme, Postmodernizm ve Siyasal İslam”, Kaygı, 9(17): 121-136.

Haffar, B. (2013) Suriye İhvan Siyasi Ofis Eski Genel Sekreteri Basil Haffar ile görüşme, mülakatı yapan: B. Gürpınar, 4 Kasım, Fatih, İstanbul. 
Hassan, H. (2013) "How The Muslim Brotherhood Hijacked Syria’s Revolution" [çevrimiçi], The Foreign Policy, 13 Mart, http://www.foreignpolicy.com/articles/2013/03/13/how_the_muslim_brotherhood_ hijacked_syria_s_revolution [erişim tarihi: 10.04.2014].

Hinnebusch, R. A. (1982) “The Islamic Movement in Syria: Sectarian Conflict and Urban Rebellion in an Authoritarian Populist Regime”, içinde Ali E. Hillal Dessouki (der.), Islamic Resurgence in the Arap World, Praeger, New York, 138-169.

Hürriyet (2014) "Cenevre'de 2. Tur Kriz Havasıyla Bitti”, 16 Şubat.

Kara, İ. (2011) “İslamcı Söylemin Kaynakları ve Gerçeklik Değeri”, Y. Aktay,

M. Gültekingil ve T. Bora (der.), Modern Türkiye’de Siyasi Düşünce Cilt 6/ İslamcllık içinde, İstanbul: İletişim Yayınları, 34-48.

Karaman, H. (2012) “Müslüman Kardeşler”, Yeni Şafak, 13 Mayıs.

Karpat, K. (2001) The Politicization of Islam: Reconstructing Identity, State, Faith, and Community in The Late Ottoman State, New York: Oxford University Press.

Lawson, F. H. (1982) “Social Bases of the Hamah Revolt," Merip Reports, 12(9): 24-28.

Lia, B. (2012). Müslüman Kardeşler’in Doğuşu, İstanbul: Ekin Yayınları.

Lund, A. (2010) "The Syria Muslim Brotherhood: Leadership Transition from Bayanouni to Shafa" [çevrimiçi], Syria Comment, 21 Ağustos, http://www.joshualandis.com/blog/?p=7037 [erişim tarihi: 20.12.2012].

Lund, A. (2011) "Weakening Regime, Weaker Opposition" [çevrimiçi], Near East Quarterly, 15 Haziran, 5, http://www.neareastquarterly.com/index.php/2011/06/15/weakening-regime-weaker-opposition/? output=pdf [erişim tarihi: 20.12.2013].

Mardin, Ş. (1992) “İslamcılık”, Cumhuriyet Dönemi Türkiye Ansiklopedisi Cilt 7 içinde, İstanbul: İletişim Yayınları, 1400-1404.

Martin, R. C. (der.) (2004) Encyclopedia of Islam and The Muslim World, New York: Macmillan Reference.

Martin, R. C. ve A. Barzegar (2010) Islamism: Contested Perspectives on Political Islam, California: Stanford University Press.

MAZLUMDER(2011) “Suriye İçin İstanbul Buluşması” [çevrimiçi], http://malatya.mazlumder.org/faaliyetler/ detay/basin-aciklamalari/1/suriye-icin-istanbul-bulusmasi/2735 [erişim tarihi: 11.02.2014].

Mehmet, O. (2011) “Bize En Uygun Model Türkiye”, Yeni Şafak, 2 Nisan.

Middle East Watch (1991) Syria Unmasked: The Suppression of Human Rights by the Assad Regime, New Haven: Yale University Press.

Milliyet (2011) “Gelecekse Türkler Gelsin”, 18 Kasım.

Milliyet (2013) "Suriye Muhalefetinde Başbakan Çatlağı”, 25 Mart.

Orhan, O. (2012) "Suriye Müslüman Kardeşler Hareketi Lideri Muhammed Riyad El Şukfa İle Söyleşi” [çevrimiçi], ORSAM, 21 Aralık, http://orsam.org.tr/tr/yazigoster.aspx?ID=4166 [erişim tarihi: 06.01.2014].

Oweis, K. Y. (2011) “INTERVIEW-Muslim Brotherhood supports anti-Assad protests” [çevrimiçi], Reuters, 11 Nisan, http://www.reuters.com/article/2011/04/11/syria-brotherhood-idaflde73a1ez20110411 [erişim tarihi: 06.02.2014].

Pargeter, A. (2010) The Muslim Brotherhood: From Opposition To Power, London: Saqi Books.

Pierret, T. (2012) “Syria: Old-Timers and Newcomers", R. Wright (der.), The Islamists Are Coming: Who They Really Are içinde, United States Institute of peace, 71-81. 
Pierret, T. (2014) “The Syrian Baath Party and Sunni Islam: Conflicts and Connivance”, Middle East Brief, 77: 1-8.

Rabil, G. G. (2010) “The Syrian Muslim Brotherhood”, B. Rubin (der.), The Muslim Brotherhood: The Organization and Policies of a Global Islamist Movement içinde, New York: Palgrave Macmillan, 73-89.

Rabinovich, I. (1972) Syria Under the Ba'th 1963-66: The Army-Party Symbiosis, Jerusalem: Israel Universities Press.

Radikal (2005). “Emil Lahud Kıskaçta”, 24 Ekim.

Radikal (2012) “Libyadan Gelen Silahlar Kardeşler’e Gitti”, 15 Eylül.

Radikal (2013a) "Suriye Muhalefetine İki Şok Birden”, 24 Mart.

Radikal (2013b) "Muhalif Cephede Yeni Şok”, 25 Mart.

Radikal (2013c) "Araplar Silahı Meşrulaştırdı", 28 Mart.

Roy, O. (2005) Siyasal İslamın İflası, İstanbul: Metis Yayıncılık.

Rubin, B. (2007) The Truth About Syria, New York: Palgrave Macmillan.

Rubin, B. (2010) The Muslim Brotherhood: The Organization and Policies of a Global Islamist Movement, New York: Palgrave Macmillan.

Salem, N. (2012) “Muslim Brotherhood Reasserting Its leadership of Syria’s Fractured Opposition” [çevrimiçi], http://www.muslimedia.com/archives/oaw02/syr-ikhwan.htm [erişim tarihi: 14.01.2014].

Seale, P. (1965) The Struggle for Syria: A Study of Post-War Arab Politics 1945-1958, London: Oxford University Press.

Shadid, A. (2005), "Inside and Outside Syria, a Debate to Decide the Future" [çevrimiçi], Washington Post, 9 Kasım, http://www.washingtonpost.com/wp-dyn/content/article/2005/11/08/AR2005110802070. html [erişim tarihi: 22.12.2013].

Shepard, W. E. (1996) Sayyid Qutb and Islamic Activism: A Translation and Critical Analysis of Social Justice in Islam, Brill Academic Pub.

Sly, L. (2011) "Syrian Opposition Unites in Exile" [çevrimiçi], Washington Post, 2 Haziran, http:// www.washingtonpost.com/world/middle-east/syrian-opposition-unites-in-exile/2011/06/01/ AGjEEoGH_story.html [erişim tarihi: 27.12.2013).

Son Dakika (2014). “Esad: Seçimlerde Adaylık İhtimalim Yüksek” [çevrimiçi], http://www.sondakika.com/ haber/haber-esad-secimlerde-adaylik-ihtimalim-yuksek-5565398/ [erişim tarihi: 17.02.2014].

Syria Monitor (2006a). "Bayanouni interview (6/7)," Center for Liberty in the Middle East, Washington, D.C., 08 Haziran.

Syria Monitor (2006b) "News Round-Up (8\29-9\1)”, 28 Eylül.

Syrian National Council (2011) [çevrimiçi] http://www.syriancouncil.org/ [Erişim Tarihi: 27.12.2012].

Talhamy, Y. (2012) “The Syrian Uprising: The Muslim Brotherhood Reborn”, Middle East Quarterly, 19(2): $33-40$.

Taştekin, F. (2014) "Halep Affetmeyecek”, Radikal, 28 Ocak.

Teitelbaum, J. (2004) “The Muslim Brotherhood and the 'Struggle for Syria', 1947-1958, Between Accommodation and Ideology", Middle Eastern Studies, 40(3): 134-158.

Tekin, Y. ve B. Akgün (2011) “İslamcılar-Demokrasi İlişkisinin Tarihi Seyri”, Y. Aktay, M. Gültekingil ve T. Bora (der.), Modern Türkiye’de Siyasi Düşünce Cilt 6/ İslamcılık içinde, İstanbul: İletişim Yayınları, 652-664. 
Thomas, L. Jr. (2011) “In Turkey's Example Some See Map For Egypt” [çevrimiçi], The New York Times, 5 Şubat Çevrimiçi: http://www.nytimes.com/2011/02/06/world/middleeast/06turkey.html [erişim Tarihi: 14.12.2013].

Türköne, M. (1994) Siyasi Bir İdeoloji Olarak İslamcılı̆̆ın Doğuşu, İstanbul: İletişim Yayınları.

Van Dam, N. (2000) Suriye'de İktidar Mücadelesi, İstanbul: İletişim Yayıncılık.

Weismann, I. (2001) Taste of Modernity: Sufism, Salafiyya, and Arabism in Late Ottoman Damascus, Leiden: Brill.

Weismann, I. (2010) "Democratic Fundamentalism? The Practise and Discourse of The Muslim Brothers Movement in Syria", Muslim World, 100: 1-16.

Wictorowicz, Q. (2004) Islamic Activism, Indiana University Press.

Wright, R. (2008) Dreams and Shadows: The Future of the Middle East, Penguin Press.

Yakın Doğu Haber (2013) "Salih Müslim: Suriye İhvan’ı Erdoğan’ın Hizmetinde” [çevrimiçi], http://www. ydh.com.tr/HD10723_salih-muslim--suriye-ihvani-erdoganin-hizmetinde.html, [erişim tarihi: 22.12.2013].

Zeyrek, D. (2012) “Suriye İçin Hicab Formülü”, Radikal, 06 Kasım.

Zisser, E. (2005) “Syria, the Ba'th Regime and the Islamic Movement: Stepping on a New Path?”, The Muslim World, 95(January): 43-65. 